\author{
JERZY SUPERNAT \\ ORCID: 0000-0002-4590-0980 \\ Uniwersytet Wrocławski \\ jerzy.supernat@uwr.edu.pl
}

\title{
Badanie samorządu terytorialnego w Europie. Przykład Europejskiej Grupy Administracji Publicznej (European Group for Public Administration — EGPA)
}

\begin{abstract}
Abstrakt: Artykuł zawiera syntetyczne omówienie badań samorządu terytorialnego prowadzonych przez Stałą Grupę Badawczą nr 5: Samorząd Regionalny i Lokalny Europejskiej Grupy Administracji Publicznej (European Group for Public Administration - EGPA). Poczynając od momentu utworzenia w 2010 roku, Grupa 5 w coraz szerszym zakresie angażuje się w porównawcze badanie samorządu terytorialnego w Europie, stając się uznanym europejskim forum dla subnarodowej administracji i subnarodowego rządzenia.
\end{abstract}

Słowa kluczowe: samorząd regionalny, samorząd lokalny, Europa, badania porównawcze, Europejska Grupa Administracji Publicznej.

\section{Europejska Grupa Administracji Publicznej}

Prowadzenie badań, w tym badań porównawczych, nad samorządem terytorialnym w Europie jest uzasadnione tym, że w większości państw europejskich wykonywanie prawnie uregulowanych zadań publicznych oraz świadczenie usług należy w znacznym (jeżeli nie dominującym) stopniu do zdecentralizowanych regionalnych i - w szczególności — lokalnych jednostek samorządu terytorialnego $^{1}$. Funkcjonowanie i wydatki samorządów regionalnych i lokalnych stano-

${ }^{1}$ Do pionierów badań porównawczych samorządu terytorialnego należą w Polsce twórcy wrocławskiej Szkoły Nauki Administracji i Prawa Administracyjnego Profesorowie T. Bigo i F. Longchamps. Fakt ten mocno podkreślają rocznicowe publikacje poświęcone dorobkowi naukowemu 
wią znaczącą część zarówno produktu krajowego brutto, jak i ogółu wydatków publicznych państw członkowskich Unii Europejskiej. Ostatnie procesy decentralizacyjne $\mathrm{w}$ wielu państwach europejskich ${ }^{2}$ niewątpliwie sprzyjają wzmocnieniu roli samorządów regionalnego i lokalnego, czemu także służy uznanie samorządu terytorialnego przez Unię Europejską, znajdujące wyraz w traktacie lizbońskim³ ${ }^{3}$. Z perspektywy politycznej (demokratycznej) samorządy regionalny i lokalny pełnią ważną stabilizującą i legitymizującą funkcję $\mathrm{w}$ ramach systemów państwowych, a także w przestrzeni suprapaństwowej. Obywatelom i mieszkańcom stwarzają możliwość bezpośredniego angażowania się w decyzyjne procesy polityczne ${ }^{4}$ i zapewniają przestrzenną bliskość dla politycznego rozwiązywania problemów ${ }^{5}$. Samorząd terytorialny odgrywa zatem kluczową rolę dla akceptacji i efektywnego funkcjonowania demokratycznych rządów w państwach europejskich.

Powyższe argumenty przesądziły o tym, że badanie samorządu terytorialnego stało się istotną częścią badań administracji publicznej w Europie prowadzonych przez Europejską Grupę Administracji Publicznej (European Group for Public Administration - EGPA). Grupa została utworzona w 1975 roku w ramach Międzynarodowego Instytutu Nauk Administracyjnych (International Institute of Administrative Sciences - IIAS) i jest regionalnym (europejskim) towarzystwem naukowym, prowadzącym badania nad teorią i praktyką administracji publicznej6.

Profesorów oraz recepcji Ich seminalnych prac. Należy do nich praca: Tadeusz Bigo o administracji i prawie administracyjnym — refleksje wrocławskiej szkoły administratywistycznej, red. T. Kocowski, P. Lisowski i M. Paplicki, Wrocław 2020.

2 Zob. J.B. Auby, The Transformation of the Administrative State and Administrative Law, [w:] The Max Planck Handbooks in European Public Law, t. 1. The Administrative State, red. A. von Bogdandy, P.H. Huber, S. Cassese, Oxford 2017, s. 601 n.

3 Traktat o Unii Europejskiej w art. 4 ust. 2 zdanie pierwsze stanowi: „Unia szanuje równość Państw Członkowskich wobec Traktatów, jak również ich tożsamość narodową, nierozerwalnie związaną z ich podstawowymi strukturami politycznymi i konstytucyjnymi, w tym w odniesieniu do samorządu regionalnego i lokalnego". Szerzej zob. J. Korczak, Europejskie wpływy na funkcjonowanie samorzadu terytorialnego w Polsce, „Przegląd Prawa i Administracji” 114, 2018, s. 327 n.

${ }^{4}$ Możliwość wypowiadania i angażowanie się obywateli w sprawy lokalne sprzyja kształtowaniu tożsamości społecznej wspólnoty i budowaniu identyfikacji z jednostkami subnarodowymi, co z kolei wzmacnia gotowość samorządu terytorialnego i państwa do innowacji. Na temat tezy, że lojalność zachęca do innowacji zob. A.O. Hirschman, Exit, Voice, and Loyalty. Responses to Decline in Firms, Organizations, and States, London 1978, s. 78. Na marginesie: jak ważna jest lojalność wobec Europy, pokazał nam Brexit.

${ }^{5}$ Istnienie przestrzeni politycznej dla lokalnej demokracji odróżnia zwykłą administrację lokalną (lokalne administrowanie zadań określonych przez administrację rządową) od (politycznej) decentralizacji, dewolucji i samorządu terytorialnego. Na temat samorządu terytorialnego jako ,istotnego elementu konstrukcji władz publicznych" zob. H. Izdebski, Polski samorzqd terytorialny w Europie. Aktualne problemy i wyzwania, [w:] Samorzad terytorialny w Polsce i w Europie. Aktualne problemy i wyzwania, red. K. Czarnecki, A. Lutrzykowski, R. Musiałkiewicz, Włocławek 2017, s. 15 n.

${ }^{6}$ Więcej zob. E. Ongaro, Introduction: The Past and the Future of a Community at the Heart of the Administrative Sciences, [w:] Public Administration in Europe. The Contribution of EGPA, red. E. Ongaro, London 2019, s. 1 n. 
Swoją działalność Grupa prowadzi zasadniczo za pośrednictwem stałych grup badawczych, z których samorządem terytorialnym zajmuje się głownie i przede wszystkim utworzona w 2010 roku Grupa 5 (Permanent Study Group 5: Regional and Local Government ${ }^{7}$ ), a z perspektywy politycznej także Grupa 4 (Permanent Study Group 4: Local Governance and Democracy ${ }^{8}$ ). Naukowe dokonania Europejskiej Grupy Administracji Publicznej zostały w 2019 roku przedstawione w okolicznościowej publikacji przygotowanej na przypadające w 2015 roku czterdziestolecie działalności EGPA: Public Administration in Europe. The Contribution of EGPA. W rozdziale 15 tej publikacji został przedstawiony syntetycznie dorobek Grupy 5 (dalej Grupa), który stanowił źródło inspiracji wielu prac wymienionych w obszernym wykazie literatury do rozdziału, obejmującym 70 pozycji.

\section{Badanie samorządu terytorialnego}

S. Kuhlmann, M. Laffin, and E. Wayenberg — autorzy rozdziału 15., poświęconego samorządowi terytorialnemu, podkreślają porównawczą orientację badań prowadzonych przez Grupę, wśród których wyróżniają i omawiają trzy obszary badawcze, najbardziej znaczące dla rozwoju teoretycznego i empirycznego porównawczego badania samorządu terytorialnego. Autorzy zaliczyli do nich: 1) systemy samorządowe lokalne i regionalne, 2) reformy subnarodowe oraz 3) rządzenie wieloszczeblowe (multi-level governance - MLG) ${ }^{9}$. Poniżej zostaną przedstawione najważniejsze ustalenia poczynione przez Grupę w tych obszarach, a w następnym punkcie obecne i przyszłe, bardziej szczegółowe tematy, które Grupa uznaje za najważniejsze w przedziale do 2055 roku.

\subsection{Badania systemów samorządowych lokalnych i regionalnych}

Badania systemów samorządowych lokalnych i regionalnych mają na celu identyfikację wymiarów i wskaźników kluczowych dla prowadzenia badań porównawczych, a następnie grupowanie (typologię) krajowych systemów samorzą-

7 Zob. S. Kuhlmann, M. Laffin, E. Wayenberg, Subnational Government in the Research Spotlight: The Merit of EGPA Permanent Study Group 5. Permanent Study Group 5: Regional and Local Government, [w:] Public Administration in Europe..., s. 147 n.

8 Zob. T. Bergström et al., Combining European Research on Local Governance and Local Democracy. Permanent Study Group 4: Local Governance and Democracy, [w:] Public Administration in Europe..., s. 135 n.

9 S. Kuhlmann, M. Laffin, E. Wayenberg, op. cit., s. 148. 
dowych lokalnych i regionalnych w oparciu o te wymiary i wskaźniki ${ }^{10}$. W dotychczasowych badaniach Grupa zidentyfikowała przede wszystkim trzy aspekty analityczne, które uznaje za kluczowe wymiary porównawczego badania samorządu terytorialnego ${ }^{11}$. Grupa nazywa je profilami (profiles), zaliczając do nich: funkcjonalny, terytorialny i polityczny. Profil funkcjonalny dotyczy zakresu i znaczenia zadań (functional responsibilities), które przypadają subnarodowym organom terytorialnym w ramach wertykalnej dystrybucji (ale i fuzji) zadań między poziomy centralny, regionalny i lokalny. Należy zauważyć, że elementem profilu funkcjonalnego jest autonomia finansowa. Profil terytorialny dotyczy z kolei struktury terytorialnej i powiązanej z tym zdolności terytorialnej samorządu terytorialnego (territorial viability). Ostatni z wyróżnionych profili, polityczny, obejmuje takie kwestie, jak: rodzaj demokracji lokalnej (przedstawicielska — bezpośrednia), stosunek między radą i lokalnymi organami wykonawczymi oraz procedura wyboru organu wykonawczego (wybór bezpośredni - wybór pośredni).

Najciekawsze i najważniejsze w badaniach Grupy jest to, że przedstawione wymiary (profile) można zestawiać w kolejne bardziej kompleksowe porównawcze typologie, pozwalające rozwijać i wzbogacać koncepcyjną podstawę badań porównawczych w Europie. Pozwala to z kolei wyróżnić nowe typy i klastry lokalnych i regionalnych systemów samorządowych, pogłębiając teoretyczną i praktyczną wiedzę o instytucjonalnych podstawach i rzeczywistym funkcjonowaniu samorządu terytorialnego w Europie. Szczególnym przykładem i produktem prowadzonych badań jest porównawczy indeks autonomii lokalnej (Local Autonomy Index - LAI), który stanowi możliwą odpowiedź na pytanie o sposób komparatywnego badania stopnia autonomii lokalnej w różnych państwach ${ }^{12}$. Prowadzone badania, zwłaszcza profilu funkcjonalnego, były istotne między innymi dla samego zdefiniowania autonomii lokalnej ${ }^{13}$, która jest jedną z kluczowych cech rzeczywistego samorządu terytorialnego.

10 Prowadzone badania porównawcze obejmują w coraz szerszym zakresie kraje Europy Centralnej i Wschodniej, zwłaszcza po roku 1990. W nie tak odległym czasie badanie z tego obszaru stanowiły „brakujące ogniwo w porównawczym badaniu samorządu terytorialnego” (a missing link in comparative local government research); zob. S. Kuhlmann, M. Laffin, E. Wayenberg, op. cit., s. 149. W tym kontekście zob. P. Swianiewicz, An Empirical Typology of Local Government Systems in Eastern Europe, „Local Government Studies” 40, 2014, nr 2, s. 292 n. Prowadzenie badań porównawczych, obejmujących Polskę umożliwia między innymi publikowanie monografii w językach obcych (współ)autorstwa pracowników Katedry Prawa Samorządu Terytorialnego Uniwersytetu Śląskiego w Katowicach, poświęconych polskiemu samorządowi terytorialnemu, których przykładem jest: Organizacja i funkcjonowanie samorzadu terytorialnego w Polsce i w Niemczech. Analiza prawnoporównawcza, red. J. Jagoda, Warszawa 2018.

${ }^{11} \mathrm{Na}$ temat metodologicznego znaczenia tertium comparationis w badaniach porównawczych zob. m.in. M. Van Hoecke, Methodology of Comparative Legal Research, „Law and Method” 2015, s. 27-28.

12 Zob. S. Kuhlmann, M. Laffin, E. Wayenberg, op. cit., s. 150.

13 Pojęcie autonomii lokalnej jest w doktrynie szeroko i od dawna dyskutowane. Zob. m.in. M. Goldsmith, Autonomy and City Limits, [w:] Theories of Urban Politics, red. D. Judge, G. Stocker, H. Wolman, London 1995, s. 228 n. 


\subsection{Badania reform subnarodowych}

Badając reformy subnarodowe, Grupa zwróciła przede wszystkim uwagę na niedostatek tych badań w zestawieniu z badaniami koncentrującymi się niemal wyłącznie na poziomie administracji krajowej (centralnej) ${ }^{14}$. Wskazano, że reformy na poziomie centralnym, w tym inspirowane przez Nowe Publiczne Zarządzanie (New Public Management - NPM) i jego sukcesorów (post-NPM) zmieniają warunki funkcjonowania samorządów regionalnego i lokalnego, a także same te samorządy, notabene różnie $\mathrm{w}$ różnych krajach ${ }^{15}$, co powinno być przedmiotem badań z międzynarodowej perspektywy porównawczej. Odnośnie do reform inspirowanych przez NPM grupa wskazała, że w niektórych krajach przyniosły one znaczące zmiany instytucjonalne, ale w innych krajach reformy te były krytykowane czy nawet ignorowane, prowadząc do skupieniu uwagi na innych rozwiązaniach (other-than-NPM-measures) w europejskich systemach samorządu terytorialnego, takich jak: reformy terytorialne, funkcjonalna realokacja w systemie wieloszczeblowym i innowacje demokratyczne ${ }^{16}$. Nie ulega wątpliwości, że przyczyniły się one do transformacji systemów i układów samorządu terytorialnego w Europie. W ostatnich badaniach prowadzonych przez Grupę szczególną uwagę zwrócono na następujące typy subnarodowych reform administracyjnych: zmiana wielkości jednostek samorządowych (territorial re-scaling), reorganizacja świadczenia usług lokalnych (re-organizing local service delivery) i reformy zarządzania (managerial reforms).

Zmiana, a de facto powiększanie (terytorialne i demograficzne) jednostek samorządowych (territorial up-scaling/amalgamation) ma w tle kryzys finansowy i wprowadzane w państwach europejskich instrumenty oszczędnościowe w połączeniu z nadzieję krajowej klasy politycznej, że takie reformy przyniosą ekonomię skali i zwiększą administracyjną efektywność samorządu terytorialnego. Alternatywą dla powiększania jednostek samorządowych w niektórych krajach z małymi jednostkami samorządowymi, często utworzonymi jeszcze w XVII wieku i od tego czasu niezmienionymi, jest tworzenie organów międzygminnych (inter-municipal bodies) i współpraca międzygminna (inter-municipal cooperation), co w odróż-

$14 \mathrm{~W}$ tych okolicznościach warto wskazać na porównawczą pracę poświęconą samorządowi terytorialnemu z perspektywy europejskiej autorstwa współautorek rozdziału 15: E. Wayenberg, S. Kuhlmann, Comparative Local Government Research: Theoretical Concepts and Empirical Findings from a European Perspective, [w:] The Palgrave Handbook of Public Administration and Management in Europe, t. 2, red. E. Ongaro, S. van Thiel, London 2018, s. 841 n. Praca ta zawiera między innymi liczne relewantne typologie, w tym typologie reform samorządu terytorialnego.

15 Zob. M. Decastri, F. Buonocore, Organizing Public Administration, [w:] Organizational Development in Public Administration. The Italian Way, red. M. Decastri et al., London 2021, s. 3 n.

16 Na temat ewolucji zarządzania publicznego z perspektywy izomorfizmu instytucjonalnego zob. A. Chrisidu-Budnik, Od biurokracji do New Public Governance, Wrocław 2019. 
nieniu od up-scaling nazywa się trans-scaling ${ }^{17}$. Takie rozwiązania mają zapewnić wykonalność zadań (operative viability) nawet w bardzo małych gminach.

Reorganizacja świadczenia usług lokalnych w państwach europejskich, które przyjęły inspirowaną przez NPM politykę eksternalizacji usług do podmiotów prywatnych i trzeciego sektora polega na przyjęciu inspirowanej przez post-NPM polityki remunicypalizacji wcześniej przekazanych na zewnątrz zadań lokalnych (post-NPM re-municipalization of previously externalized local functions). W tej mierze istotne jest odróżnienie decentralizacji politycznej, powiązanej z przekazywaniem radom lokalnym rzeczywistych uprawnień decyzyjnych w odniesieniu do nowo transferowanych zadań administracyjnych, od decentralizacji administracyjnej rozumianej jako transfer zadań administracyjnych ze szczebla centralnego do samorządu terytorialnego bez przyznania mu kompetencji politycznych.

Reformy zarządzania w jednostkach samorządu terytorialnego inspirowała idea NPM transformacji biurokratycznej administracji weberowskiej w przyjazne dla klienta przedsięwzięcie usługowe (service enterprise) zarządzane w sposób zorientowany na wykonanie i wyniki (managed in a performance-oriented manner $)^{18}$. Wśród licznych zmian Grupa zidentyfikowała zwłaszcza: reorganizację wewnętrzną, reinżynierię procesową, nowe systemy budżetowe i księgowe, zarządzanie zorientowane na wyniki oraz modernizację zarządzania zasobami ludzkimi. Przy czym radykalne reformy menedżerskie usług publicznych (managerialization of the public services) miały miejsce w Zjednoczonym Królestwie (i Nowej Zelandii), ale już nie w większości państw Europy kontynentalnej. Nie oznacza to, że reformy menedżerskie na kontynencie były nieistotne czy minimalne, a jedynie to, że nie były rewolucyjne. Było w szczególności tak, że różne systemy samorządowe przystosowały reformy zarządzania do swoich odrębnych kontekstów społecznych i kulturowych, co potwierdza, iż administracja publiczna jest zjawiskiem społeczno-kulturowym ${ }^{19}$.

17 Zob. H. Baldersheim, L.E. Rose, Territorial Choice. Rescaling Governance in European States, [w:] Territorial Choice: The Politics of Boundaries and Borders, London 2010, s. $1 \mathrm{n}$.

18 Ta nowa perspektywa znalazła wyraz między innymi w nazwie węgierskiej ustawy o postępowaniu administracyjnym z 2004 roku: Act on the General Rules of Public Administrative Procedure and Performances. Ustawa ta rozróżnia w obrębie administracji publicznej administrację państwową i administrację samorządową, a także klasyczną administrację ingerującą (interfering administration) i nowszą administrację zorientowaną na wyniki (performing administration), zob. H. Küpper, Evolution and Gestalt of the Hungarian State, [w:] The Max Planck Handbooks..., s. 325. Na temat późniejszych regulacji postępowania administracyjnego na Węgrzech zob. A. Patyi, Hungary, [w:] Administrative Proceedings in the Habsburg Succession Countries, red. Z. Kmieciak, Łódź-Warszawa 2021, s. 129 n.

19 Zob. F. Longchamps, Założenia nauki administracji, Wrocław 1949, a z prac nowszych M.W. Bauer, Public Administration and Political Science, [w:] The Palgrave Handbook of Public Administration and Management in Europe, t. 2, s. 1049 n. 
Prowadzenie przez Grupę badań wyróżnionych typów subnarodowych reform administracyjnych pozwoliło na zmniejszenie wskazanej powyżej luki w badaniach porównawczych przez uwzględnienie znaczącego spektrum reform samorządowych z europejskiej perspektywy porównawczej. Uwzględnienie w tych badaniach reform NPM i post-NPM oraz podejść alternatywnych umożliwia w coraz większym stopniu odpowiedź na fundamentalne pytanie o to, jakie podejścia do reform lokalnego sektora publicznego można zidentyfikować z międzynarodowej perspektywy porównawczej oraz jak można je wyjaśnić ${ }^{20}$.

\subsection{Badania rządzenia wieloszczeblowego (MLG)}

W badaniach rządzenia wieloszczeblowego grupa wskazała na paradoks polegający na tym, że wieloszczeblowość (multilevelledness) jest uznawana za fundamentalną cechą charakterystyczną współczesnego państwa ${ }^{21}$, ale pomimo to większość badań koncentruje się na interakcji między poziomami europejskim i narodowym (państwowym) w europejskim systemie wieloszczeblowym, zaniedbując badanie poziomów regionalnego i lokalnego ${ }^{22}$. Stąd badania podejmowane przez Grupę w ostatnich latach w coraz większym stopniu orientują się na eliminację tego deficytu badawczego. W badaniach tych w szczególności bierze się pod uwagę wpływ całościowych reform administracyjnych (intergovernmental reforms) na zdolność organizacyjną władz lokalnych (local governance capacities).

Koncepcja rządzenia wieloszczeblowego odgrywa także kluczową rolę dla analizowania funkcji sterującej i koordynującej samorządów lokalnego (i regionalnego) w otoczeniu wieloszczeblowym. W tym obszarze zostały wyodrębnione dwa typy idealne MLG: terytorialny model wielozadaniowy (the territorially based multi-purpose model - typ I MLG), który jest oparty na racjonalności terytorialnej, oraz model jednozadaniowy (the single-purpose model — typ II MLG), który jest oparty na racjonalności funkcjonalnej. W typie I samorząd lokalny łączy instytucjonalnie wszystkie przyznane zadania i ma terytorialny ogólny mandat do podejmowania decyzji i świadczenia usług. Tym samym model ten odnosi się do horyzontalnej terytorialnie zorientowanej organizacji administracyjnej, w której gmina jako jednostka administracyjna łączy i wykonuje na własną odpowiedzialność wszystkie zadania relewantne dla społeczności lokalnej. Wielozadaniowy samorząd lokalny ma mandat do zdefiniowania dobra wspólnego wspólnoty lo-

20 Zob. S. Kuhlmann, M. Laffin, E. Wayenberg, op. cit., s. 153.

21 Zob. Public Administration and the Modern State. Assessing Trends and Impact, red. E. Bohne et al., London 2014.

22 Zob. S. Kuhlmann, M. Laffin, E. Wayenberg, op. cit., s. 153. Zob. też przegląd tematów badań w obszarze administracji publicznej i zarządzania publicznego w Europie po drugiej wojnie światowej: E. Ongaro et al., Public Administration and Public Management Research in Europe: Traditions and Trends, [w:] The Palgrave Handbook of Public Administration and Management in Europe, t. 1, s. $11 \mathrm{n}$. 
kalnej i zatem równoważenia działań licznych aktorów jednozadaniowych (single-purpose actors) o specyficznych interesach. Z kolei typ II stanowi wertykalną funkcjonalnie zorientowaną jednostkę administracyjną, w której istnieje scentralizowana struktura organizacyjna w przestrzeni od poziomu centralnego do poziomu lokalnego, a odpowiedzialność polityczna za lokalnie administrowane zadania leży poza samorządem terytorialnym. Odpowiedzialność polityczna i administracyjne wykonanie w typie II są instytucjonalnie rozdzielone, a funkcje lokalne są horyzontalnie rozszczepione (unbundled) i powierzone podmiotom wyspecjalizowanym (mono-functional actors). Ogólnie można powiedzieć, że bardziej kompleksowe badania rządzenia wieloszczeblowego z uwzględnieniem zamierzonych i niezamierzonych skutków zmian inicjowanych na poziomie centralnym w przestrzeni subnarodowej zmniejszają wskazany deficyt badawczy, chociaż niewątpliwie potrzebne są dalsze badania w obszarze, który ciągle jeszcze może być uznawany za brakujące ogniwo w porównawczym badaniu samorządów lokalnego i regionalnego ${ }^{23}$.

\section{Teraźniejszość i przyszłość}

Przedstawione powyżej kierunki badań samorządów lokalnego i regionalnego przez Europejską Grupę Administracji Publicznej pozwalają stwierdzić, że Grupa szczególną uwagę poświęca dwom grupom zagadnień. Po pierwsze, wpływom kryzysu gospodarczego i polityki oszczędnościowej (dążenia do redukcji deficytu i znaczącego obcinania wydatków publicznych) na rolę i funkcjonowanie samorządu terytorialnego, zmieniające się relacje pomiędzy poziomami samorządu terytorialnego oraz między nimi a rządem centralnym. Notabene, utrzymująca się polityka oszczędnościowa przynosi zwiększony nacisk na samorządy lokalny i regionalny, prowadzący do wewnętrznych reorganizacji i różnych ,innowacji”, stanowiących odpowiedź na naciski i ograniczenia finansowe. Ograniczenia finansowe nie pozostają też bez wpływu na relację między samorządem regionalnym i samorządem lokalnym. Dają się tutaj zaobserwować dwa przeciwstawne zjawiska, a mianowicie z jednej strony „centralizm regionalny” (regional centralism), z drugiej - harmonijna współpraca pomiędzy samorządem regionalnym i samorządem lokalnym. Po drugie, biorąc pod uwagę zwiększoną działalność reformatorską i reorganizacyjną w samorządzie terytorialnym, którą przyniosło Nowe Publiczne Zarządzanie z zamiarem wyparcia biurokratycznego Starego Publicznego Zarządzanie (Old Public Management - OPM), Grupa szczególną uwagę poświęca reformom, strategiom i wpływom Post-NPM. Jest przy tym interesujące i ważne, że reformy Post-NPM nie zawsze mają na celu „odwrócenie”

23 Zob. S. Kuhlmann, M. Laffin, E. Wayenberg, op. cit., s. 155. 
reform i menedżerskich narzędzi NPM, a jedynie ich dostosowanie do nowych uwarunkowań, co przynosi swoiste postaci hybrydowości ${ }^{24}$. Zatem obok remunicypalizacji obserwujemy adaptację zarządzania zorientowanego na skuteczność i wyniki (performance management), wydajność, koordynację, odpowiedzialność, elastyczność i otwartość ${ }^{25}$. W konkretnym przypadku ocen pracowniczych obserwujemy oprócz podejścia zorientowanego na przestrzeganie przepisów (conformance assessment) podejście zorientowane na ocenę wyników (performance assessment $)^{26}$. Badając powyższe kwestie Grupa współpracowała blisko z europejską siecią badawczą the COST Action Local Public Sector Reforms (LocRef), badającą reformy publiczne na poziomie subnarodowym (sub-national level of government).

Wybiegając w rok 2055, Grupa zamierza kontynuować badania nad wskazanymi powyżej zagadnieniami, w tym nad odpornością i trwałością istniejących instytucji i rządowo-samorządowych relacji w okresie, w którym administracja publiczna staje wobec wyzwań bez precedensu w okresie powojennym. Wyzwania te przynoszą ze sobą szanse dla samorządu terytorialnego, jak na przykład digitalizacja administracji, ale także rozliczne zagrożenia, których listę powiększyła ostatnio pandemia koronawirusa ${ }^{27}$. Zarówno szanse, jak i zagrożenia wymagają, jak wskazuje Grupa, kontynuacji prowadzonych przez nią badań porównawczych ${ }^{28}$. Stanowisko takie zasługuje na pełną aprobatę, a z punktu widzenie wyzwań wobec których stoi samorząd terytorialny istotne jest to, że prowadzone przez Grupę badania są nie tylko akademickie (koncepcyjne, analityczne), ale mają także mocną warstwę empiryczną i praktyczną. I jeżeli nawet prace Grupy nie przynoszą zawsze gotowych do zastosowania rozwiązań, to należy pamiętać, że prawdziwa wartość badań porównawczych leży nie tylko w udzielanych odpowiedziach, lecz także w pytaniach, do których prowokująa ${ }^{29}$.

${ }^{24}$ Na przykładzie Norwegii zob. K. Fossestøl et al., Managing institutional complexity in public sector reform: Hybridization in front-line service organizations, „Public Administration” 93, 2015, nr 2, s. $290 \mathrm{n}$.

25 Zob. A. Hinna, F. Ceschel, Public Management Reform in Italy, [w:] Organizational development..., s. $105 \mathrm{n}$.

26 Zob. R. Reina, D. Scarozza, Human Resource Management in the Public Administration, [w:] Organizational development..., s. $61 \mathrm{n}$.

27 Należy zauważyć, że wszystkie możliwości i zagrożenia wobec których stoi administracja publiczna mają zawsze wymiar prawny. Na przykład digitalizacja administracji powoduje wyłanianie się prawa komunikacji elektronicznej. Zob. A. Monarcha-Matlak, Wpływ komunikacji elektronicznej na prawo administracyjne, [w:] Prawo administracyjne dziś i jutro, red. J. Jagielski, M. Wierzbowski, Warszawa 2018, s. 152 n.

28 Zob. S. Kuhlmann, M. Laffin, E. Wayenberg, op. cit., s. 159.

29 Zob. E.A. Young, A Comparative Perspective, [w:] Oxford Principles of European Union Law, t. 1. The European Union Legal Order, red. R. Schutze, T. Tridimas, Oxford 2018, s. 188. 


\section{Bibliografia}

Auby J.B., The Transformation of the Administrative State and Administrative Law, [w:] The Max Planck Handbooks in European Public Law, t. 1. The Administrative State, red. A. von Bogdandy, P.H. Huber, S. Cassese, Oxford 2017.

Baldersheim H., Rose L.E., Territorial Choice. Rescaling Governance in European States, [w:] Territorial Choice: The Politics of Boundaries and Borders, London 2010.

Bauer M.W., Public Administration and Political Science, [w:] The Palgrave Handbook of Public Administration and Management in Europe, t. 2, red. E. Ongaro, S. van Thiel, Palgrave MacMillan, London 2018.

Bergström T., Copus C., Franzke J., Ruano J.M., Schaap L., Vakkala H., Combining European Research on Local Governance and Local Democracy. Permanent Study Group 4: Local Governance and Democracy, [w:] Public Administration in Europe. The Contribution of EGPA, red. E. Ongaro, London 2019.

Chrisidu-Budnik A., Od biurokracji do New Public Governance, Wrocław 2019.

Decastri M., Buonocore F., Organizing Public Administration, [w:] Organizational Development in Public Administration. The Italian Way, red. M. Decastri, S. Battini, F. Buonocore, F. Gagliarducci, London 2021.

Fossestøl K., Breit E., Andreassen T.A., Klemsdal L., Managing institutional complexity in public sector reform: Hybridization in front-line service organizations, „Public Administration” 93, 2015, $\mathrm{nr} 2$.

Goldsmith M., Autonomy and City Limits, [w:] Theories of Urban Politics, red. D. Judge, G. Stocker, H. Wolman, London 1995.

Hinna A., Ceschel F., Public Management Reform in Italy, [w:] Organizational Development in Public Administration. The Italian Way, red. M. Decastri, S. Battini, F. Buonocore, F. Gagliarducci, London 2021.

Hirschman A.O., Exit, Voice, and Loyalty. Responses to Decline in Firms, Organizations, and States, London 1978.

Izdebski H., Polski samorzad terytorialny w Europie. Aktualne problemy $i$ wyzwania, [w:] Samorzad terytorialny w Polsce $i$ w Europie. Aktualne problemy $i$ wyzwania, red. K. Czarnecki, A. Lutrzykowski, R. Musiałkiewicz, Włocławek 2017.

Korczak J., Europejskie wptywy na funkcjonowanie samorzadu terytorialnego w Polsce, „Przegląd Prawa i Administracji” 114, 2018.

Kuhlmann S., Laffin M., Wayenberg E., Subnational Government in the Research Spotlight: The Merit of EGPA Permanent Study Group 5. Permanent Study Group 5: Regional and Local Government, [w:] Public Administration in Europe. The Contribution of EGPA, red. E. Ongaro, London 2019.

Küpper H., Evolution and Gestalt of the Hungarian State, [w:] The Max Planck Handbooks in European Public Law, t. 1. The Administrative State, red. A. von Bogdandy, P.H. Huber, S. Cassese, Oxford 2017.

Longchamps F., Założenia nauki administracji, Wrocław 1949.

Monarcha-Matlak A., Wpływ komunikacji elektronicznej na prawo administracyjne, [w:] Prawo administracyjne dziś i jutro, red. J. Jagielski, M. Wierzbowski, Warszawa 2018.

Ongaro E., Introduction: The Past and the Future of a Community at the Heart of the Administrative Sciences, [w:] Public Administration in Europe. The Contribution of EGPA, red. E. Ongaro, London 2019.

Ongaro E., van Thiel S., Massey A., Pierre J., Wollmann H., Public Administration and Public Management Research in Europe: Traditions and Trends, [w:] The Palgrave Handbook of Public Administration and Management in Europe, t. 1, red. E. Ongaro, S. van Thiel, London 2018.

Prawo 333, 2021

(C) for this edition by CNS 
Organizacja i funkcjonowanie samorzadu terytorialnego $w$ Polsce $i w$ Niemczech. Analiza prawnoporównawcza, red. J. Jagoda, Warszawa 2018.

Patyi A., Hungry, [w:] Administrative Proceedings in the Habsburg Succession Countries, red. Z. Kmieciak, Łódź-Warszawa 2021.

Public Administration and the Modern State. Assessing Trends and Impact, red. E. Bohne, E. Graham, J.C.N. Raadschelders, J.P. Lehrke, London 2014.

Reina R., Scarozza D., Human Resource Management in the Public Administration, [w:] Organizational Development in Public Administration. The Italian Way, red. M. Decastri, S. Battini, F. Buonocore, F. Gagliarducci, London 2021.

Swianiewicz P., An Empirical Typology of Local Government Systems in Eastern Europe, „Local Government Studies" 40, 2014, nr 2.

Tadeusz Bigo o administracji i prawie administracyjnym — refleksje wroctawskiej szkoły administratywistycznej, red. T. Kocowski, P. Lisowski i M. Paplicki, Wrocław 2020.

Van Hoecke M., Methodology of Comparative Legal Research, „Law and Method” 2015.

Wayenberg E., Kuhlmann S., Comparative Local Government Research: Theoretical Concepts and Empirical Findings from a European Perspective, [w:] The Palgrave Handbook of Public Administration and Management in Europe, t. 2, red. E. Ongaro, S. van Thiel, London 2018.

Young E.A., A Comparative Perspective, [w:] Oxford Principles of European Union Law, t. 1. The European Union Legal Order, red. R. Schutze, T. Tridimas, Oxford 2018.

\section{Research on Territorial Self-Government in Europe: The Example of the European Group for Public Administration (EGPA)}

Summary

The text offers a concise description of the contribution and relevance of EGPA Permanent Study Group 5: Regional and Local Government to research of territorial self-government in Europe. Since its launch in 2010, Group 5 has been more and more involved in comparative research on regional and local government, thus becoming a renowned European forum on subnational government and governance.

Keywords: regional government, local government, Europe, comparative research, EGPA. 